The Quarterly Journal of Austrian Economics

Volume 23 | NO. 2 | 152-170 | SuMMER 2020 WWW.QJAE.ORG

\title{
Clearinghouse Certificates during THE GReAt Depression: A Non-EXAMPLE OF "UNACCOUNTED MONEY"
}

\author{
Clifford F. Thies*
}

JeL Classification: B53, E14, E51, N12

Aвstract: This article examines the non-issue of bank clearinghouse certificates during the Great Depression of the 1930s. Instead of a market failure, this non-issue is found to have been the result of an intervention. At the time, the issue of clearinghouse certificates to temporarily meet the need of the economy for a medium of exchange following a financial panic was a well-established practice. To make a long story short: In 1933, plans were underway by bankers to resort to this expedient. Merchants and the public at large were anxious to get their hands on the money substitute. But federal authorities said no. Instead of a short-term fix, following which the economy would return to its former ways, federal authorities had other plans. This paper examines both the specifics of the issue of emergency money during the Great Depression and the general principles involved in such issues.

\section{INTRODUCTION}

A ccording to Paul Krugman (1999, 8-11), a contributing cause to a depression is hoarding. Because of hoarding, the government

\footnotetext{
*Clifford F. Thies (cthies@su.edu) is Eldon R. Lindsey Chair of Free Enterprise Professor of Economics and Finance at Shenandoah University. He thanks two anonymous referees for their constructive criticism and absolves them of any fault for remaining errors and shortcomings.
} 
should issue massive amounts of money to prevent recessions from turning into depressions. But, why must the government do this? Why can't the private sector issue money during an emergency? At one level, the answer is easy: the government has monopolized money and prohibits the private sector from issuing money during an emergency. At another level, the answer is complicated.

Relying on numismatic sources, Richard Timberlake (1981, 860) demonstrated that the private sector repeatedly issued massive amounts of money during the hard times of the early to mid $19^{\text {th }}$ century. While there appears to have been some number of issues throughout the period, private, non-bank issues of money mostly appeared during certain times (1814-17, 1837-40, 1857-58, and 1862-64). Timberlake describes this money as "unaccounted." Subsequent research has documented other instances of unaccounted money including Michigan when the state was nearly without banks (Baily, Hossain and Pecquet 2018), and New Orleans when it was occupied by northern troops during the Civil War (Pecquet and Thies 2010). During the National Bank Era, clearinghouse associations took the lead in issuing money during financial crises (Dwyer and Gilbert 1989, Gorton 1985). So why was there no clearinghouse money during the Great Depression of the 1930s?

In 1999, when Krugman wrote The Return of Depression Economics, it was received strangely. It was a thin book, written in large type, short on economics and long on story-telling. Supposedly, it was about Japan's "lost decade," when-according to Krugman-they had not increased their national debt enough. Yet, Japan's national debt had grown to 200 percent of GDP. Krugman updated the book, The Return of Depression Economics and the Crisis of 2008 (2008). In the update, his concern was that the U.S., with a budget deficit of 12 percent of GDP, was not adding to its national debt fast enough.

To illustrate the problem of hoarding, Krugman used the example of the Capitol Hill Baby-Sitting Co-op of Washington, D.C., of the 1970s. As Krugman describes this co-op, it consisted of lawyers and other such well-heeled persons who decided that, instead of hiring baby-sitters, they would take turns baby-sitting each others' children. The co-op required that its members only obtain baby-sitting services from each other, and use chits distributed by the co-op for the service. But, the members of the co-op hoarded the chits they had (in order to have them available when they really needed baby-sitting services), 
rather than use them freely in order to go out. And, since few people were purchasing baby-sitting services, nobody could be sure of acquiring chits through the offer of baby-sitting services, which only served to reinforce the urge to hoard chits.

After trying various New Deal-type "solutions" to the hoarding problem, such as requiring members to go out at least twice a month, the Co-op happened upon the idea of distributing more chits. The additional chits allayed members' concerns that had led to the hoarding problem, and the market in baby-sitting services picked up.

What does Krugman's story of the hoarding of baby-sitting chits have to do with depressions? During depressions, people lose confidence in their ability to earn money by offering their labor and other productive services. They therefore seek to build up cash reserves, i.e., to "hoard money." But, the Keynesian story goes, the hoarding of money lowers the demand for labor and other productive services, resulting in a further loss of confidence, and intensifying the urge to hoard.

Other examples of hoarding come readily to mind. During the coronavirus panic of 2020, there was a run on toilet paper. Because people were not confident in future supplies of the item, they rushed to buy it, and emptied the shelves. Voila! stores ran out of toilet paper, just as panicked shoppers feared. But the shortage was only temporary, and the supply chain quickly restored retail inventories.

Throughout most of the world, replacement kidneys are in short supply as most people "hoard" their extra kidney not being confident of being able to obtain a replacement kidney if the need should arise. But not in Iran, where the authorities allow an internal market in kidneys. In that country, replacement kidneys are in good supply (Fry-Revere 2014).

In 1834, in conjunction with the failure of one bank (the Bank of Maryland) and rumors about others, there was a run on the banks of Baltimore. People lined up at banks to demand their specie (Niles' Reporter, March 29, 1834). But, as the day wore on, those in line saw others leaving their banks with their bags and wheelbarrows heavy with coins, and-their fears allayed-people began leaving the line. Later in the day, some who had earlier gotten their specie were returning their coins to their banks. Accordingly, there was no general suspension. 
Each of these examples indicates that a government intervention is not always needed to solve a hoarding problem (interpreting allowing a market in Iran as reduced involvement by government). Even the example cited by Krugman was resolved by the BabySitting Co-op without a government intervention.

There is more to what is called the "hoarding" of money than the impact of income uncertainty on what the Keynesians call aggregate demand. ${ }^{1}$ Historically, times of hoarding were times of bank suspensions and of runs on the bank, and sometimes they were also times of uncertainty regarding the gold standard and runs on the dollar. ${ }^{2}$

The impact of hoarding can be particularly severe with a fractional reserve banking system. In a fractional reserve banking system, every dollar removed from banks forces a multiple reduction of the money supply. Furthermore, a "run on the bank" might result in banks being forced into suspension, immobilizing the funds still in them. The run of the bank can force a suspension even if the bank has positive net worth and reserves sufficient to meet the run because maintaining a certain amount of reserves is required by law or regulation.

In the past, when banks suspended, a great deal of the money people had in their banks became illiquid, meaning that it was unavailable as a medium of exchange. The combination of reduced consumer confidence, job insecurity, a reduced money supply, money tied up in banks in suspension, concerns for additional bank failures, and speculation on gold caused people to cut back on their spending either for lack of income or in order to build-up a cash reserve, and deprived the economy of a portion of its medium of exchange.

\footnotetext{
${ }^{1}$ The connotation that hoarding is anti-social can be said to be at least as old as Jesus' parable of the talents, in which the master scolds the servant who had buried the money entrusted with him, instead of depositing it with a banker so that the master, upon his return, could have received his capital with interest (Matthew 25: 14-28). But it is difficult to distinguish the socially-useful purposes of such things as the buffer stocks of business, strategic reserves of a country, and the liquidity services of cash balances, from anti-social behavior, and easy to blame the public for the loss of confidence in banks.

${ }^{2}$ There clearly was a run on the dollar in conjunction with the Panic of 1893 . This run on the dollar was only ended by the dramatic repeal of the Sherman Silver Purchase Act of 1890 during an extraordinary session of Congress called by President Grover Cleveland (Timberlake 1993, 166-82; see also Calomiris 1993, Thies 2005).
} 
To be sure, hoarding might not have been a primary cause of a recession. Hoarding might have only broken out when the public became concerned for the soundness of money and/or of the banking system, and thus may have been a secondary cause making a recession worse. In the monetary history of the United States, money generally disappeared only after banks were forced into suspension.

The great champion of the gold standard Ludwig von Mises recognized the usefulness of money substitutes to deal with bank panics. "[I]t has repeatedly happened in times of crisis that confidence has been destroyed," he said (Mises 1953, 371). This loss of confidence in bank deposits would result in "a collapse of a part of the national business organization" if allowed to run its course. In England, the Bank of England emitted additional bank notes; and, in the United States, which had no central bank, clearing house certificates were emitted (372). Even though such actions seemed to violate the "rules of the game" of the gold standard, Bordo and Kydland $(1996,85)$ say these actions may have supported the commitment to the gold standard in the long run.

F.A. Hayek (1967, 109), in an often-misunderstood passage, described the phenomenon as a "secondary depression." Walter Bagehot's dictum, that central bankers should lend freely on good collateral to solvent banks at high interest rates during panics, would seem to obviate the effects of hoarding; but, what if there is no central bank (as during the National Bank era); and, what if the central bank does not follow his rule?

\section{CLEARINGHOUSE ASSOCIATIONS}

During the National Bank Era, and with some acquiescence by law and regulation, ${ }^{3}$ the market developed an effective method to deal with the problems of bank suspension and hoarding through the issue of scrip, or emergency money, by banks and their clearinghouse associations. Originally, this emergency money was used only among banks. But, over time, at first in the South and

\footnotetext{
${ }^{3}$ Hepburn (1924, 351-52) mentions the prohibitory federal tax on privately issued banknotes that was not enforced during financial panics, because of the emergency conditions. There were also state and federal laws directly prohibiting the issue of banknotes, or treating them as counterfeits of U.S. currency.
} 
then elsewhere, this clearinghouse money came to have a more general circulation. To be sure, clearinghouse money was not the only measure employed by the market to deal with the bank suspension and hoarding problems. But clearinghouse money became, by far, the most significant measure during the National Bank Era. According to A. Piatt Andrew (1908), following the Panic of 1907, when $\$ 238$ million of clearing house certificates were issued, \$96 million of other forms of scrip were also issued. The largest component of these other forms of scrip were payroll checks written by employers.

As A.D. Noyes (1909) details, following the Panic of 1893, the New York Clearing House issued \$38.3 million in clearinghouse certificates, and other clearinghouses across the country issued a total of $\$ 69$ million. These certificates circulated for about 19 weeks, at which time, the panic having ended, they were withdrawn from circulation, and normal operations resumed. Following the Panic of 1907, the New York Clearing House issued \$85.4 million in clearinghouse certificates. Including clearinghouses across the country, a total of \$238 million was issued. These certificates circulated for about 22 weeks.

Clearinghouse certificates had been issued following prior panics, in 1873, 1884 and 1890. Table 1 gives the amounts issued by the New York Clearing House from 1873 to 1907. An antecedent of clearinghouse certificates was utilized as early as 1857 . That year, a form of clearinghouse certificate "backed" by securities issued by New York State and the U.S. Treasury was used for inter-bank settlements (Gibbons 1968, p. 364). This expedient was subsequently utilized several times during the 1860s. ${ }^{4}$

\footnotetext{
${ }^{4}$ Swanson (1908) describes the first issue of clearing house certificates during the 1860s. Camp (1892) sketches the early history of the New York Clearing House, including its periodic issue of clearing house certificates.
} 
Table 1. Clearinghouse Certificates Issued by the New York Clearing House Association from 1873 to 1907

\begin{tabular}{|l|l|l|l|l|l|}
\hline $\begin{array}{l}\text { Date first } \\
\text { issued }\end{array}$ & $\begin{array}{l}\text { Date last } \\
\text { issued }\end{array}$ & $\begin{array}{l}\text { Date first } \\
\text { cancelled }\end{array}$ & $\begin{array}{l}\text { Date last } \\
\text { cancelled }\end{array}$ & $\begin{array}{l}\text { Total } \\
\text { issued }\end{array}$ & $\begin{array}{l}\text { Maximum } \\
\text { outstanding }\end{array}$ \\
\hline $9 / 22 / 1873$ & $11 / 20 / 1873$ & $10 / 3 / 1873$ & $1 / 14 / 1874$ & $26.6 \mathrm{M}$ & $22.4 \mathrm{M}$ \\
\hline $5 / 15 / 1884$ & $6 / 6 / 1884$ & $5 / 19 / 1884$ & $9 / 23 / 1884$ & $24.9 \mathrm{M}$ & $21.9 \mathrm{M}$ \\
\hline $11 / 12 / 1890$ & $12 / 22 / 1890$ & $11 / 28 / 1890$ & $2 / 7 / 1891$ & $16.6 \mathrm{M}$ & $15.2 \mathrm{M}$ \\
\hline $6 / 21 / 1893$ & $9 / 6 / 1893$ & $7 / 6 / 1893$ & $11 / 1 / 1893$ & $41.5 \mathrm{M}$ & $38.3 \mathrm{M}$ \\
\hline $10 / 26 / 1907$ & $1 / 30 / 1908$ & $11 / 14 / 1907$ & $3 / 28 / 1908$ & $101.1 \mathrm{M}$ & $88.4 \mathrm{M}$ \\
\hline
\end{tabular}

Source: Sprague (1910, 432-23)

It was in 1873 that certified checks payable through clearinghouses were first issued as hand-to-hand currency. For example, soon following the decision of the New York Clearing House to adopt the Clearing House Certificate method for inter-bank clearings, the Louisville Clearing House suspended payments in legal tender currency ("greenbacks") and paid out, instead, small checks based on the pledge of securities with the clearinghouse ([Memphis] Public Ledger, September 29, 1873, p. 2).

In 1893, clearinghouse certificates were first issued as a handto-hand currency (Cannon 1910, 3). These retail-level certificates were mostly issued by clearinghouse associations in the South. In addition, checks issued by banks, manufacturers and others, suitable for use as a hand-to-hand currency, became commonplace. The Richmond Dispatch (August 12, 1893, p. 2) reports that these expedients worked well. Thousands of workers were paid in the scrip, which was in turn freely accepted by merchants. ${ }^{5}$ A numismatic catalogue details dozens of specimens of certified checks issued by banks, clearinghouse certificates and manufacturer's payroll checks that were issued during this financial panic (Shafer and Shaheen 2013).

In 1907, small-denomination clearinghouse certificates were issued by clearinghouse associations in several regions of the country. As discussed above, the dollar amount of clearinghouse certificates issued approximately doubled the amount issued in

\footnotetext{
${ }^{5}$ To be sure, the next day, even while reporting that the certified check system continued to work well, the newspaper reported that some mercantile houses refused the scrip.
} 
conjunction with the financial panic of 1893 . Hundreds of specimens of scrip issued by clearinghouses, banks, manufacturers and others are described in Shafer and Shaheen's (2013) catalogue.

In 1914, to offset financial tightness upon the outbreak of World War I, clearinghouse associations issued \$200 million of inter-bank clearinghouse certificates (see Table 2), and "currency associations" organized by national banks issued $\$ 400$ million in (emergency) National Bank notes under the Aldrich-Vreeland Act of 1907 ("The 1914 issue of ..." 1915, 509). These banknotes were not backed by U.S. Treasury bonds, but rather by qualifying securities such as state and municipal bonds and commercial paper; and, the issue was subject to a penalty interest rate. Because of the penalty interest rate on these issues of National Bank notes, they were quickly retired from circulation when the period of financial stringency passed, as were the clearinghouse certificates. Shafer and Shaheen's (2013) catalogue contains only a few specimens of scrip for this period.

Table 2. Clearinghouse Certificates Issued by the Clearinghouse Associations during 1914

\begin{tabular}{|l|l|l|l|l|l|l|}
\hline & $\begin{array}{l}\text { Date first } \\
\text { issued }\end{array}$ & $\begin{array}{l}\text { Date last } \\
\text { issued }\end{array}$ & $\begin{array}{l}\text { Date first } \\
\text { cancelled }\end{array}$ & $\begin{array}{l}\text { Date last } \\
\text { cancelled }\end{array}$ & $\begin{array}{l}\text { Total } \\
\text { issued }\end{array}$ & $\begin{array}{l}\text { Maximum } \\
\text { outstanding }\end{array}$ \\
\hline New York & $8 / 3$ & $10 / 15$ & $8 / 26$ & $11 / 28$ & $124.7 \mathrm{M}$ & $109.2 \mathrm{M}$ \\
\hline Chicago & $8 / 4$ & $10 / 14$ & $10 / 2$ & $12 / 14$ & $42.1 \mathrm{M}$ & $41.9 \mathrm{M}$ \\
\hline Philadelphia & $8 / 3$ & $10 / 2$ & $10 / 16$ & $11 / 28$ & $11.5 \mathrm{M}$ & $11.5 \mathrm{M}$ \\
\hline Boston & $8 / 4$ & $10 / 5$ & $10 / 7$ & $11 / 24$ & $11.4 \mathrm{M}$ & $11.4 \mathrm{M}$ \\
\hline St. Louis & $8 / 5$ & $9 / 2$ & $9 / 8$ & $12 / 10$ & $10.9 \mathrm{M}$ & $10.7 \mathrm{M}$ \\
\hline Baltimore & $8 / 4$ & $9 / 15$ & $8 / 13$ & $12 / 9$ & $2.3 \mathrm{M}$ & $2.2 \mathrm{M}$ \\
\hline New Orleans & $8 / 4$ & $8 / 5$ & $8 / 23$ & $10 / 23$ & $2.2 \mathrm{M}$ & $2.2 \mathrm{M}$ \\
\hline St. Paul & $8 / 5$ & $8 / 18$ & $8 / 29$ & $11 / 7$ & $2.0 \mathrm{M}$ & $2.0 \mathrm{M}$ \\
\hline Minneapolis & $8 / 6$ & $8 / 29$ & $9 / 30$ & $11 / 5$ & $1.9 \mathrm{M}$ & $1.9 \mathrm{M}$ \\
\hline Detroit & $8 / 5$ & $8 / 13$ & $10 / 8$ & $11 / 9$ & $1.4 \mathrm{M}$ & $1.4 \mathrm{M}$ \\
\hline Louisville & $8 / 5$ & $8 / 5$ & $12 / 1$ & $12 / 1$ & $1.2 \mathrm{M}$ & $1.2 \mathrm{M}$ \\
\hline Des Moines & $8 / 6$ & $8 / 15$ & $8 / 15$ & $11 / 7$ & $0.2 \mathrm{M}$ & $0.2 \mathrm{M}$ \\
\hline
\end{tabular}

Source: William B. Dana Co. $(1915,510)$ 


\section{HOW DID CLEARINGHOUSE CERTIFICATES WORK?}

Initially and in the case of the New York Clearing House until its aborted issue of 1933, clearinghouse certificates were issued by clearinghouses in the making of loans to member banks in large denominations, secured by "good funds" attested to by the clearinghouse association, for the purpose of inter-bank settlements. As demonstrated by Gorton and Tallisman (2018), soon after the issue of these clearinghouse certificates by the New York Clearing House, the premium on currency relative to certified checks fell from about 5 to about 1 percent, restoring liquidity to the nation's financial center. Bank and stock market suspensions were minimized or avoided altogether.

Outside of New York, financial panics often had lingering effects, including (1) partial or full suspension of cash withdrawals from banks, (2) difficulties in meeting payrolls, (3) dislocation of domestic exchange, (4) hoarding, (5) a currency premium, and (6) the issue of hand-to-hand money substitutes (Wicker 2000; James et al 2013). Banks and clearinghouse associations issued scrip to the public, variously described as cashier's checks, certified checks and clearinghouse certificates, in small denominations suitable for a hand-to-hand currency. The clearinghouse certificates were typically "backed" by identified assets of clearinghouse member banks, and mutually guaranteed by the clearinghouse member banks. In addition, manufacturers and other businesses issued payroll checks in the manner of due bills, payable upon resumption of normal banking or by a certain date; and, merchants issued scrip redeemable in merchandise.

The bank and clearinghouse scrip were typically lent to an employer, who used them to meet a payroll, or else issued to depositors looking to make withdrawals during a time of suspension. Workers and depositors who received the bank and clearinghouse scrip then tendered them, like money, to various merchants (which is not to say that the merchants had to accept them, since they were not legal tender). Receivers of the scrip might use them to repay their loans from banks, or to make deposits in accounts at banks. Otherwise, they might themselves use the scrip as money. As long as the supply of bank scrip and clearinghouse certificates is small compared to the need of debtors to banks for money with which to make their loan payments, the bank scrip and clearinghouse certificates would pass at or near par. 
Thus, among the ways the bank scrip and clearinghouse certificates worked is that they were created in the process of making loans, and destroyed in the process of paying off loans. Also, they were issued to depositors during the time banks were in suspension, and destroyed when used to pay off loans or when re-deposited. During the brief time of their existence, they circulated as money for a temporary period of time under emergency conditions.

\section{SCRIP DURING THE GREAT DEPRESSION}

If bank scrip and clearinghouse certificates moderated the effects of financial panics during the National Bank Era, why were they not issued during the Great Depression? The reason bankers did not, during the Great Depression, rescue the country from the worst series of bank panics in U.S. monetary history, is, first, the job of lender of last resort had been transferred from clearinghouse associations to the Federal Reserve; and, second, the government stopped the banks from issuing clearinghouse certificates. The clearinghouse associations, spontaneously and motivated by self-interest, developed the expedient of clearinghouse certificates to deal with financial crisis. The newly formed Federal Reserve, contrariwise, was to act with discretion and in the public interest. In hindsight, it is clear that clearinghouses acted dependably and even reflexively as a lender of last resort; while the Federal Reserve during its formative years thrashed about.

During March 1933, following the suspensions of many banks, several state bank holidays, and a looming national bank holiday, the bankers of the country, joined by merchants and others, were ready to issue hundreds of millions of dollars in clearinghouse certificates. But the government intervened and prevented it.

Prior to 1933, bankers had mostly resisted the call for scrip. Nevertheless, a number of localities had availed themselves of the same. According to the New York Times (January 15, 1933, IV:8), by early 1933, about 500,000 people were using some form of scrip. Some municipalities issued scrip in the payment of salaries to their workers and for other purposes. For example, Atlantic City, New Jersey, issued scrip during 1932, receivable by the city for payment 
of back taxes. Again according to the New York Times (March 3, 1933, p. 36), "The scrip [of Atlantic City] has had a wide circulation and much of it has reached the office of Tax Collector Lewis L. Mathis for delinquent bills."

In other cases, voluntary associations issued scrip in conjunction with work relief efforts. In Freeport, New York, for example, the Freeport Committee for Unemployment, with the support of "virtually all stores" in the town, issued \$50,000 in "stamp scrip." This emergency money was to be issued to persons in payment for work on make-work projects, and was then to be spent in the stores of the town that would accept it. It was to re-circulate within the town for the next year. A fund for the redemption of the scrip was to accumulate through the purchase of stamps for affixing on the scrip, at the rate of 2 percent of its face value per transaction or per week. While the stamp scrip idea was one of the more inventive schemes that arose during the Great Depression of the 1930s, it should be considered that such difficult times often give rise to panaceas that, somehow, "solve the underlying problem" of a market economy (Myers 1940).

The private issue of scrip during the 1930s was given some impetus by the issue of wooden currency in 1931 by the chamber of commerce of Tenino, Washington (Brown 1941, 22-25; Preston 1933). ${ }^{6}$ This scrip ranged in denomination from $25 \$$ to $\$ 10$, was printed on a thin slice of wood composite material, and was backed by the frozen assets of the suspended local bank. The scheme, born out of the need of the town for a medium of exchange when its one and only bank suspended, caught the fancy of the nation, and became something of a novelty item for tourists. Many subsequent issues by chambers of commerce and similar business groups, individual merchants and other community-based associations featured elements of both novelty and need. Table 3 describes some of the characteristics of the scrip outstanding in 1933. ${ }^{6}$ Brown's $(1941)$ master's thesis provided a panoramic view of scrip during the Great
Depression. Contemporary works include Elvins $(2005,2010)$ and Gatch $(2008,2012)$. 
Table 3. Scrip issued during selected financial panics from 1893 to 1933

\begin{tabular}{l|l|l|l|}
\hline & 1893 & 1907 & 1933 \\
\hline Specimens in catalogues & 166 & 1,219 & 3,138 \\
\hline \multicolumn{4}{|l}{$\%$ of issues by $\ldots$} \\
\hline State and Municipal governments, agencies & 7.1 & 0.2 & 23.0 \\
\hline Banks and Clearinghouses & 50.6 & 79.3 & 27.7 \\
\hline Manufacturers, etc. ${ }^{[1]}$ & 42.4 & 20.5 & 39.5 \\
\hline Relief organizations ${ }^{[2]}$ & - & - & 9.9 \\
\hline Stamp scrip (any issuer) ${ }^{[3]}$ & - & - & 10.6 \\
\hline \multicolumn{4}{|l|}{ of issues that included denominations of ... } \\
\hline Less than $\$ 1$ only & 2.4 & 0.6 & 9.1 \\
\hline Both & 2.4 & 0.6 & 19.2 \\
\hline \$1 or more only & 95.3 & 98.4 & 69.9 \\
\hline
\end{tabular}

[1] includes merchants, mining companies, railroads and other transportation companies, chambers of commerce and other business associations, and community-based associations

[2] includes voucher-like chits distributed by work relief efforts; and, exchange certificates issued by labor cooperatives

[3] double-counts certain issues by governments, chambers of commerce and other business and community-based organizations

Sources: Mitchell and Shafer (1984), Shafer and Sheehan (2013)

Notice, in Table 3, how dramatically different were the issues of scrip outstanding in 1933 from those of the prior two major financial crises. During the prior two financial crises, banks and their clearinghouse associations made the majority of issues of scrip; and, together with manufacturers and others in the private, for-profit sector, dominated the issue of scrip. In contrast, in 1933, there was no clear locus. Issuers of scrip were simply diverse. Also during the prior two financial crises, almost all scrip was in denominations of at least $\$ 1$. In contrast, in 1933, a lot of scrip was fractional currency. The changed composition of scrip reflects the more deranged financial conditions of the 1930s. Bankers, with their ability to recognize value in loan-making and, hence, to enhance the liquidity of the assets and earning power securing those loans, were being replaced by amateurs. 
By March 1933, the problems with bank suspension, bank holidays and hoarding had become unbearable. Following the election of Franklin D. Roosevelt, and the possibility of radical legislation or even rule by decree, people throughout the country rushed to withdraw their money from banks. Banks were failing in droves, and, in one state after another, bank holidays were being declared or else withdrawals of deposits were being restricted to 5 percent of balances. In some places, moratoria were being declared on debt payments, and there was a growing suspicion that gold would be embargoed.

Instead of allaying the fears of the public, these bank holidays and other interventions only made things worse. Money started disappearing, including in particular coins and small-denomination paper currency. There was a run on the change-making machines at laundromats, and retailers stopped accepting high-denomination bills for small purchases.

On March $4^{\text {th }}$, when New York Governor Herbert H. Lehman declared a two-day bank holiday, banker sentiment shifted sharply in favor of scrip. That day, the New York Clearing House announced a rush plan to issue clearinghouse certificates upon the re-opening of the banks. At the printing facilities of the American Bank Note Company in the Bronx, crews started working round the clock to deliver up to $\$ 200$ million in scrip to the New York Clearing House, in denominations from $\$ 1$ to $\$ 50$, with additional orders by bankers in Baltimore, Boston, Chicago, Detroit, Philadelphia and elsewhere.

Throughout New York City, merchants and other vendors started announcing their readiness to accept the scrip, as well as bank checks, and their willingness to extend store credit to regular customers. According to the New York Times (March 7, 1933, p. 5), "There was something naïve in the anxiety of the public to get its hands on the promised new medium of exchange." But representatives of the New York, Philadelphia, Baltimore and Richmond clearinghouse associations were then called to Washington, D.C., by the Secretary of the Treasury. After a few days of negotiation, including an apparent approval of the bankers' plans, authority to proceed with the issue of clearinghouse certificates was denied. Instead of allowing clearinghouse certificates, the administration pushed the Emergency Banking Act of 1933 through Congress. Among other things, this act gave the Federal Reserve enormous 
new power to issue currency. This was soon followed by executive orders and other legislation fundamentally changing the character of money and banking in the country.

\section{PROBLEMS WITH SCRIP}

From time to time during the National Bank Era, bank scrip and clearinghouse certificates served a useful function. They ameliorated the problem of deflation characteristic of a fractional reserve banking system during and immediately subsequent to a bank panic. Being illegal, bank scrip and clearinghouse certificates depended on forbearance by authorities, and quickly disappeared after the emergency was over. They did not permanently add to the money stock. With a gold standard, there was a meaningful link between the money supply and gold, although an elastic one because of fractional reserve banking. During normal times, there was a tendency for the money multiplier and therefore the money supply to increase. During banks panics, the money multiplier and therefore the money supply fell precipitously, with macroeconomic consequences. There were problems attendant to returning to the gold standard after a wartime suspension, and to the periodic discoveries of gold and improvements in the technology of gold mining. Still, the gold standard provided an anchor to the price level. If bank scrip and clearinghouse certificates were permanent additions to the money stock, the price level would become indeterminate. This only happened during the 1920s, when the Federal Reserve became enamored with the Real Bills Doctrine (Humphrey and Timberlake 2019).

Bank scrip and clearinghouse certificates were an inferior form of money to legal tender currency and demand liabilities issued by banks; and, the menagerie of local currencies issued during the 1930s were even more inferior. These emergency forms of money circulated only locally and, because of their small scale, subject to a significant discount by brokers even when received at par within their locality, where brokers made markets in them. Brown (1941, 40-42) gives the example of Detroit's municipal scrip, that exchanged for legal tender currency at a discount of 5 percent. To some extent, appeals to community-mindedness overcame the inferiority of these various forms of emergency money. But, for 
the most part, the emergency money was only put into circulation through the payment of wages by state and municipal governments and private sector employers during a time of high unemployment. While there are only a few known cases of counterfeit scrip (again, Detroit's municipal scrip is an example [Brown 1941, 40-42]), this might simply be due to the fleeting existence of most issues of scrip.

\section{STATE PREROGATIVE OVER MONEY}

The market has exhibited tremendous ability to identify goods useful as media of exchange, from cattle and grain in the ancient world, to cowrie shells and wampum, to beaver pelts and deer skins, and from tobacco in colonial Virginia and cigarettes in WWII prison camps, to giant rocks on the island of Yap. George Selgin (2008) describes the private issue of coins during the industrial revolution in Great Britain. Nevertheless, the assertion of a monopoly over the medium of exchange by the governmentwhat is called its prerogative over money-has frequently cut short the private issue of money; in some cases, with devastating consequences. Sometimes, there have been rather transparent attempts to evade restrictions on privately issued currency. For example, some money substitutes during the $19^{\text {th }}$ century were declared redeemable in train fares or in merchandise so as to look like coupons and not a general medium of exchange (Timberlake 1981, 861-62). With the shortage of coins during the U.S. Civil War, some privately issued tokens in the form of copper pennies were inscribed "NOT ONE CENT", as in "Millions for defense, but NOT ONE CENT for tribute."

During the 1870s, the use as money of payroll checks and due bills issued by the mining companies of Michigan's northern peninsula was abruptly ended when these money substitutes were declared subject to the federal government's prohibitory tax on private banknotes (Thies 2019). In 2009, the issuer of the "Ron Paul dollar" was convicted of violating the federal government's law against issuing anything designed to circulate as a medium of exchange (Ramsey 2008). In contrast, the issuers of the Ithaca dollar and other "community currency" (Collom 2005, Kim, Lough and Wu 2016) have not been prosecuted, possibly because they did not threaten the system. From 1933 to 1977, the federal government not 
only banned the private ownership of gold and abrogated the gold clause in bonds, it banned all forms of indexation (McCulloch 1980).

The failure of banks to issue scrip during the Great Depression of the 1930s was not a market failure, but the result of an intervention. Instead of resorting to the proven expedient of clearinghouse certificates to meet an emergency need for a medium of exchange, the incoming administration had much bigger plans. It would be like a babysitting co-op deciding that the way to deal with the hoarding of babysitting chits is to take children away from their parents and put them into orphanages run by the co-op, instead of simply issuing enough additional chits to bring liquidity to the babysitting market.

\section{REFERENCES}

Andrew, A. Piatt. 1908. "Substitutes for Cash in the Panic of 1907." Quarterly Journal of Economics 22, no. 4: 497-516.

Baily, Christopher, Tarique Hossain, and Gary Pecquet. 2018. "Private banks in early Michigan, 1837-1884." Cliometrica 12, no. 1: 153-80.

Bordo, Michael D., and Finn E. Kydland. 1996. "The Gold Standard as a Commitment Mechanism." Pp. 55-100 in Modern Perspectives on the Gold Standard, ed. Tamim Bayoumi, Barry Eichengreen and Mark P. Taylor. London: Cambridge University Press.

Brown, Vernon. 1941. "Scrip and Other Forms of Emergency Money Issued in the United States During the Depression Years of 1931-1934." MBA thesis, New York University, 1941.

Calomiris, Charles W. 1993. "Greenback Resumption and Silver Risk: The Economics and Politics of Monetary Regime Change in the United States, 1862-1900." Pp. 86-132 in Monetary Regime Transformations, ed. Michael S. Bordo and Forest Capie. London: Cambridge University Press.

Camp, William A. 1892. "The New York Clearing House." North American Review 154: 684-90.

Cannon, James G. 1910. Clearinghouses. National Monetary Commission. Washington, DC: GPO, 1910. 
Collom, Ed. 2005. "Community Currency in the United States: The Social Environments in Which It Emerges and Survives." Environment and Planning A: Economy and Space 37, no. 9: 1565-87.

Dwyer, Gerald, and R. Alton Gilbert. 1989. "Bank Runs and. Private Remedies." Federal Reserve Bank of St. Louis Review. May/June: 43-61.

Elvins, Sarah. 2005. “Scrip Money and Slump Cures: Iowa's Experiments with Alternative Curency During the Great Depression." Annals of Iowa 64: 221-45.

— 2010. "Scrip, Stores and Cash-Strapped Cities." Journal of Historical Research in Marketing 2: 86-107.

Fry-Revere, Sigrid. 2014. The Kidney Sellers: A Journey of Discovery in Iran. Durham, NC: Carolina Academic Press.

Gatch, Loren. 2008. "Local Money in the United States During the Great Depression." Essays in Economic and Business History 26 (2008): 47-61.

— . 2012. "Tax Anticipation Scrip as a Form of Local Currency in the USA During the 1930s." International Journal of Community Currency Research 16: 22-35.

Gibbons, J.S. 1968. The Banks of New York, Their Dealers, The Clearing House and the Panic of 1857. New York: Greenwood Press.

Gorton, Gary. 1985. "Clearinghouses and the Origin of Central Banking in the U.S." Journal of Economic History 45, no. 2: 277-83.

Gorton, Gary, and Ellis W. Tallman. 2018. Fighting Financial Crises: Learning from the Past. Chicago: University of Chicago Press.

Hayek, Friedrich A. 1967. Prices and Production, $2^{\text {nd }}$ Ed. New York: A.M. Kelley.

Hepburn, A. Barton. 1915. A History of Currency in the United States. New York: Macmillan.

Humphrey, Thomas M. and Richard H. Timberlake. 2019. Gold, the Real Bills Doctrine, and the Fed: Sources of Monetary Disorder, 1922-1938. Washington, DC: Cato Institute.

James, John A. James McAndrews, and David F. Weiman. 2013. "Wall Street and Main Street: The Macroeconomic Consequences of New York Bank Suspensions, 1866-1914." Cliometrica 72: 99-130. 
Kim, Seon Mi, Benjamin Lough and Chi-Fang Wu. 2016. "The conditions and strategies for success of local currency movements." Local Economy 31, no. 3: 344-58.

Krugman, Paul. 1999. The Return of Depression Economics. New York: W.W. Norton.

- 2008. The Return of Depression Economics and the Crisis of 2008. New York: W.W. Norton.

McCulloch, J. Huston. 1980. “The Ban of Indexed Bonds, 1933-77." American Economic Review 70, no. 5: 1018-21.

Mises, Ludwig von. 1953. The Theory of Money and Credit. trans. H.E. Batson. New Haven: Yale University Press.

Mitchell, Ralph A. and Neil Shafer. 1984. Standard Catalog of Depression Scrip in the United States. Iola, Wis.: Krause Publications.

Myers, Margaret. 1940. Monetary Proposals for Social Reform. New York: Columbia University Press.

Noyes, A.D. 1909. Forty Years of American Finance. New York: Putnam.

Pecquet, Gary, and Clifford F. Thies. 2010. "Money in Occupied New Orleans, 1862-1868." Review of Austrian Economics 23, no. 2: 111-12.

Preston, Howard H. 1933. "The Wooden Money of Tenino." Quarterly Journal of Economics 47: 343-48.

Ramsey, Bruce. 2008. “The Liberty Dollar.” http://bruceramsey.net/index. php/liberty-dollar-2008/

Selgin, George. 2008. Good Money: Birmingham Button Makers, The Royal Mint, and the Beginnings of Modern Coinage 1775-1821. Anne Arbor, Mich.: University of Michigan Press.

Shafer, Neil, and Tom Sheehan. 2013. Panic Scrip of 1893, 1907 and 1914: An Illustrated Catalog of Emergency Monetary Issues, ed. Fred Reed. Jefferson, NC: McFarland.

Sprague, O.M.W. 1910. History of Crisis under the National Bank System. Washington, D.C.: GPO.

Swanson, William Walker. 1908. "The Crisis of 1860 and the First Issue of Clearing-House Certificates: II" Journal of Political Economy 16: 212-26. 
Thies, Clifford F. 2005. "Gold Bonds and Silver Agitation." Quarterly Journal of Austrian Economics 8, no. 4: 67-86.

. 2019. "Samuel J. Tilden, Iron Money and the Election of 1876." Pp. 21-30 in Public Choice Analysis of American Economic History, vol. 3, ed. Joshua Hall and Marcus Witcher. New York: Springer.

Timberlake, Richard. 1981. “The Significance of Unaccounted Currencies." Journal of Economic History 41, no. 4: 853-66.

. 1993. Monetary Policy in the United States. Chicago: University of Chicago Press, 1993.

Wicker, Elmus. 2000. Banking Panics and the Gilded Age. New York: Cambridge. University Press.

William B. Dana Co. 1915. “The 1914 Issue of Clearing-House Loan Certificates," Commercial and Financial Chronicle 100, February 13, 1915, pp. 508-10. Available at https://fraser.stlouisfed.org/title/ commercial-financial-chronicle-1339/february-13-1915-518193. 